\title{
STRUCTURES OF NEW 18-MEMBERED MACROLIDES FD-891 AND FD-892
}

\author{
Mitsuko Seki-Asano, Yukiko Tsuchida, Kazunori HaNada \\ and KazUtoshi MizouE* \\ Dept. of Research Center of Taisho Pharmaceutical Co., Ltd., \\ 1-403 Yoshino-cho, Omiya-shi, Saitama 330, Japan \\ (Received for publication June 20, 1994)
}

\begin{abstract}
Structures of FD-891 and FD-892 were determined by extensive NMR spectral analysis as shown in Fig. 1. They belong to such 18 -membered macrolides as concanamycins and virustomycin.
\end{abstract}

In the course of our screening program for low molecular substances inducing morphological changes of HL-60, new 18-membered macrolides FD-891 and FD-892 were discovered in the fermentation broth of Streptomyce graminofaciens A-88901). They belong to such 18-membered antibiotics as concanamycins $^{2,3)}$ and virustomycin ${ }^{4,5)}$. Their biological properties are similar to those of 18-membered antibiotics $^{1}$. Their structures were determined by extensive NMR analysis as shown in Fig. 1. This paper deals with their structural elucidation.

\section{Results and Discussion}

Structure of FD-891

The physico-chemical properties of FD-891 are shown in Table 1. The UV spectrum of FD-891 showed the absorption at $270 \mathrm{~nm}$ due to a diene system conjugated with a carbonyl group. The bands at 3400 and

Fig. 1. Structures of FD-891 and FD-892.<smiles>COC(C)C(C)C=C(CC=CC=CC[C](O)C1OC1C(O)C(C)C=C(C)C=C(C)C(=O)O)C(C)CCC(O)C(C)C(O)C(C)C(C)OC</smiles>

FD-891<smiles>CC1=CC(C)C(O)=CCCCC=CC=CCC(C(C)CCC(O)C(C)C(O)C(C)C(C)O)OC1=O</smiles> 
Table 1. Physico-chemical properties of FD-891 and FD-892.

\begin{tabular}{lll}
\hline & \multicolumn{1}{c}{ FD-891 } & \multicolumn{1}{c}{ FD-892 } \\
\hline Appearance & White powder & White powder \\
MP $\left({ }^{\circ} \mathrm{C}\right)$ & $68.5 \sim 72$ & $55 \sim 62$ \\
{$[\alpha]_{\mathrm{D}}$} & $+14.0^{\circ}(c 0.1, \mathrm{MeOH})$ & $+48.0^{\circ}(c 0.05, \mathrm{MeOH})$ \\
FAB-MS $(m / z)$ & $579(\mathrm{M}+\mathrm{H})^{+}$ & $533(\mathrm{M}+\mathrm{H})^{+}$ \\
HREI-MS $(m / z)$ & & \\
$\quad$ Found: & 578.3827 & 532.3759 \\
$\quad$ Faicd: & 578.3819 & 532.3764 \\
& for $\mathrm{C}_{33} \mathrm{H}_{54} \mathrm{O}_{8}$ & for $\mathrm{C}_{32} \mathrm{H}_{52} \mathrm{O}_{6}$ \\
$\mathrm{UV} \lambda$ & $208(5,060), 270(12,480)$ & $207(7,710), 275(14,040)$ \\
IR $v_{\max }^{\mathrm{KBr}} \mathrm{cm}^{-1}$ & 3400,1710 & 3400,1705 \\
\hline
\end{tabular}

$1710 \mathrm{~cm}^{-1}$ in the IR spectrum were assigned to a hydroxyl and an ester carbonyl, respectively; the existence of the latter was confirmed by the signal at $\delta_{\mathrm{C}} 168.9$ in the ${ }^{13} \mathrm{C}$ NMR spectrum.

The molecular formula was determined to be $\mathrm{C}_{33} \mathrm{H}_{54} \mathrm{O}_{8}$ by the HREI-MS measurment of its molecular ion at 578.3827 (calcd. 578.3819) in connection with its NMR spectra. The degree of unsaturation was estimated to be 7 by its molecular formula. Four unsaturations were assigned to four double bonds and one to a carbonyl group, leaving the final two unsaturation to accommodate two rings. Only 50 hydrogens could be identified through the DEPT spectra described below, indicative of the existence of four secondary hydroxyl groups by its molecular formula. The four acetyl methyl signals at $\delta_{\mathrm{H}} 2.10,2.11,2.31$ and 2.33 in the ${ }^{1} \mathrm{H}$ NMR spectrum of the tetra acetyl derivative of FD-891 confirmed the existence of four secondary hydroxyl groups in the molecule.

The ${ }^{13} \mathrm{C}$ NMR spectrum of FD-891 showed 33 signals, consistent with its molecular formula, which were classified into $\mathrm{CH}_{3} \times 7,-\mathrm{CH}_{2}-\times 4,>\mathrm{CH}-\times 4,-\mathrm{OCH}_{3} \times 1,-\mathrm{CHO}-\times 8,-\mathrm{CH}=\times 6,>\mathrm{C}=\times 2$ and 政 $\mathrm{O} \times 1$ by its DEPT spectrum.

The ${ }^{1} \mathrm{H}$ and ${ }^{13} \mathrm{C}$ NMR data are summarized in Table 2.

The initial assignment of the partial structures was based mainly on the mapping information found in the ${ }^{1} \mathrm{H}-{ }^{1} \mathrm{H}$ COSY spectrum. Though signals due to unequivalent methylenes were overlapped in the high field region, they could be unambiguously assigned on the one-to-one basis by the aid of the ${ }^{1} \mathrm{H}-{ }^{13} \mathrm{C}$ COSY spectrum.

The fragment (1) in Fig. 2 was deduced by tracing the correlation maps from the cross peak at $\delta_{\mathrm{H}}$ $4.17(\mathrm{H}-7)$ through $\delta_{\mathrm{H}} 3.12(\mathrm{H}-6)$ to those at $\delta_{\mathrm{H}} 5.55(\mathrm{H}-5), 1.15(6-\mathrm{Me})$ and through $\delta_{\mathrm{H}} 3.25(\mathrm{H}-8)$ to 3.15 (H-9) in the ${ }^{1} \mathrm{H}-{ }^{1} \mathrm{H}$ COSY spectrum. The signals for $\mathrm{H}-8$ and $\mathrm{H}-9$ showed correlation peaks with the lines at $\delta_{\mathrm{C}} 55.1$ and 56.0, respectively, in the ${ }^{1} \mathrm{H}^{13} \mathrm{C}$ COSY spectrum; their ${ }^{1} J_{\mathrm{C}-\mathrm{H}}$ coupling values were estimated to be $c a .170 \mathrm{~Hz}$. The trends of their ${ }^{13} \mathrm{C}$ chemical shifts and the measurement of their ${ }^{1} J_{\mathrm{C}-\mathrm{H}}$ coupling constant values suggested C-8 and C-9 to be an epoxide ring as shown in Fig. 2.

The signals at $\delta_{\mathrm{H}} 3.88(\mathrm{H}-10)$ made up a cross peak with the equivalent methylene at $\delta_{\mathrm{H}} 2.55\left(\mathrm{H}_{2}-11\right)$, which in turn coupled to the olefinic proton at $\delta_{\mathrm{H}} 5.64(\mathrm{H}-12)$. Thus, the fragment (2) was assigned as depicted in Fig. 2.

The signal at $\delta_{\mathrm{H}} 4.87(\mathrm{H}-17)$ coupled to the unequivalent methylene protons at $\delta_{\mathrm{H}} 2.20$ and $2.45(\mathrm{H}-16$ $\mathrm{A}$ and $\mathrm{B})$, which showed cross peaks with an olefinic proton line at $\delta_{\mathrm{H}} 5.75(\mathrm{H}-15)$ forming a correlation peak with the line at $\delta_{\mathrm{H}} 5.60(\mathrm{H}-14)$. These results revealed the fragment (3) as shown in Fig. 2.

The analysis of the ${ }^{1} \mathrm{H}-{ }^{1} \mathrm{H}$ COSY spectrum in the same way led to the assignment of the fragments 
Table 2. ${ }^{1} \mathrm{H}$ and ${ }^{13} \mathrm{C}$ chemical shifts of FD-891 and FD-892 measured in $\mathrm{CDCl}_{3}$.

\begin{tabular}{|c|c|c|c|c|}
\hline \multirow{2}{*}{ No. } & \multicolumn{2}{|r|}{ FD-891 } & \multicolumn{2}{|r|}{ FD-892 } \\
\hline & $\delta_{\mathrm{c}}$ & $\delta_{\mathrm{H}}$ & $\delta_{\mathrm{C}}$ & $\delta_{\mathbf{H}}$ \\
\hline 1 & 168.9 & & 169.8 & \\
\hline 2 & 124.3 & & 123.0 & \\
\hline 3 & 144.0 & $7.30(\mathrm{t} ; 1.3)$ & 144.4 & $7.15(\mathrm{t} ; 1.2)$ \\
\hline 4 & 135.7 & & 132.3 & \\
\hline 5 & 141.6 & $5.53($ br d; 10.3$)$ & 144.4 & $5.37(\mathrm{t} ; 1.3)$ \\
\hline 6 & 35.9 & $3.12(\mathrm{~m} ; 10.3,6.9,4.1)$ & 38.8 & $2.55(\mathrm{~m} ; 10.3,7.0,3.5)$ \\
\hline 7 & 70.8 & $4.17(\mathrm{dd} ; 4.1,6.2)$ & 78.9 & $3.85(\mathrm{~m})$ \\
\hline 8 & 55.1 & $3.25(\mathrm{dd} ; 6.0,2.5)$ & 125.5 & $5.34(\mathrm{dd} ; 9.5,15.8)$ \\
\hline 9 & 56.0 & $3.15(\mathrm{dd} ; 2.5,0.8)$ & 133.2 & 5.78 (ddd; $16.0,7.0,9.2)$ \\
\hline 10 & 71.1 & $3.55(\mathrm{~m})$ & 29.9 & $1.95(\mathrm{~m}), 2.01(\mathrm{~m})$ \\
\hline 11 & 37.9 & $2.55(\mathrm{~m})$ & 35.6 & $2.21(\mathrm{~m})$ \\
\hline 12 & 128.2 & $5.64(\mathrm{~m})$ & 128.9 & $5.41(\mathrm{~m})$ \\
\hline 13 & 129.3 & $5.55(\mathrm{~m})$ & 132.8 & $5.46(\mathrm{~m})$ \\
\hline 14 & 130.1 & $5.60(\mathrm{~m})$ & 133.2 & $5.33(\mathrm{~m})$ \\
\hline 15 & 129.0 & 5.75 (ddd; $4.5,10.2,15.2)$ & 131.9 & 5.55 (ddd; $10.0,15.2,6.0)$ \\
\hline 16 & 34.4 & $\begin{array}{l}2.20(\mathrm{ddd} ; 14.5,4.5,7.5) \\
2.45(\mathrm{ddd} ; 14.5,10.2,4.5)\end{array}$ & 34.2 & $\begin{array}{l}1.80(\mathrm{ddd} ; 10.2,5.0,14.1) \\
2.20(\mathrm{~m})\end{array}$ \\
\hline 17 & 76.7 & $4.87(\mathrm{ddd} ; 7.5,4.5,2.5)$ & 75.6 & $4.85(\mathrm{ddd} ; 10.0,2.5,5.0)$ \\
\hline 18 & 34.4 & $1.85(\mathrm{~m})$ & 37.0 & $1.78(\mathrm{~m})$ \\
\hline 19 & 35.9 & $1.95(\mathrm{~m}), 2.25(\mathrm{~m})$ & 36.4 & $1.92(\mathrm{~m}), 2.20(\mathrm{~m})$ \\
\hline 20 & 36.7 & $2.15(\mathrm{~m}), 2.30(\mathrm{~m})$ & 36.3 & $1.90(\mathrm{~m}), 2.17(\mathrm{~m})$ \\
\hline 21 & 73.3 & $3.88(\mathrm{ddd} ; 10.0,7.8,9.0)$ & 74.2 & $3.85(\mathrm{~m})$ \\
\hline 22 & 39.5 & $1.80(\mathrm{~m} ; 7.0,8.1,1.4)$ & 39.0 & $1.96(\mathrm{~m})$ \\
\hline 23 & 78.2 & $3.82(\mathrm{dd} ; 8.1,1.4)$ & 78.9 & $3.85(\mathrm{~m})$ \\
\hline 24 & 39.5 & $1.60(\mathrm{~m} ; 7.0,9.5,8.2)$ & 39.5 & $1.50(\mathrm{~m} ; 6.5,7.0,10.5)$ \\
\hline 25 & 82.5 & $3.60(\mathrm{~m} ; 6.8,9.5)$ & 72.8 & $4.10(\mathrm{~m} ; 7.0,10.5,1.5)$ \\
\hline$-\mathrm{OCH}_{3}$ & 56.0 & 3.34 & & \\
\hline $2-\mathrm{CH}_{3}$ & 13.6 & $2.10(\mathrm{~d} ; 1.2)$ & 13.6 & $2.03(\mathrm{~d} ; 1.3)$ \\
\hline $4-\mathrm{CH}_{3}$ & 15.5 & $2.03(\mathrm{~d} ; 1.2)$ & 15.4 & $1.90(\mathrm{~d} ; 1.2)$ \\
\hline $6-\mathrm{CH}_{3}$ & 16.5 & $1.15(\mathrm{~d} ; 6.9)$ & 17.2 & $1.16(\mathrm{~d} ; 6.9)$ \\
\hline $18-\mathrm{CH}_{3}$ & 16.3 & $0.88(\mathrm{~d} ; 7.0)$ & 15.0 & $0.95(\mathrm{~d} ; 7.0)$ \\
\hline $22-\mathrm{CH}_{3}$ & 11.4 & $0.80(\mathrm{~d} ; 7.1)$ & 11.9 & $0.79(\mathrm{~d} ; 7.1)$ \\
\hline $24-\mathrm{CH}_{3}$ & 5.0 & $0.90(\mathrm{~d} ; 7.0)$ & 3.9 & $0.92(\mathrm{~d} ; 7.1)$ \\
\hline $25-\mathrm{CH}_{3}$ & 16.2 & $1.20(\mathrm{~d} ; 6.8)$ & 21.3 & $1.19(\mathrm{~d} ; 7.0)$ \\
\hline
\end{tabular}

(4), (5), (6) and (7), respectively as shown in Fig. 2. The ambiguity due to the signal overlapping did not allow us to correctly assign and expand the partial structures in the ${ }^{1} \mathrm{H}-{ }^{1} \mathrm{H}$ COSY spectrum. To overcome these problems, the $\mathrm{HMBC}^{6}$ technique was applied. As the peak heights of proton signals are known to be proportional to the intensities of the cross peaks of long range couplings between ${ }^{1} \mathrm{H}$ and ${ }^{13} \mathrm{C}$ observed in the heteronuclear multiple-bond correlation (HMBC) spectrum, the HMBC experiment is a particularly effective method for structural determination of the molecule with many methyl groups ${ }^{7}$. Therefore, the assignments of the partial structures substituted with methyl groups, the elucidation of the structures replaced with singlet methyls and the connectivities of these partial structures can be performed by the use of the HMBC technique.

The singlet methyl (2-Me) at $\delta_{\mathbf{H}} 2.10$ showed the cross peaks with C-1 $\left(\delta_{\mathrm{C}} 168.9\right), \mathrm{C}-2\left(\delta_{\mathrm{C}} 124.5\right)$ and $\mathrm{C}-3\left(\delta_{\mathrm{C}} 144.0\right)$, respectively. Furthermore, the signal for $\mathrm{C}-3$ coupled with the singlet methyl $(4-\mathrm{Me})$ at $\delta_{\mathrm{H}}$ 2.03, which in turn correlated to $\mathrm{C}-4\left(\delta_{\mathrm{C}} 135.7\right)$ and $\mathrm{C}-5\left(\delta_{\mathrm{C}} 141.6\right) . \mathrm{A}^{13} \mathrm{C}-{ }^{1} \mathrm{H}$ long range coupling was observed between the carbon line due to $\mathrm{C}-5$ and the doublet methyl $(6-\mathrm{Me})$ at $\delta_{\mathbf{H}} 1.15$, which showed 
Fig. 2. Structural fragments elucidated by tracing the cross peaks in the ${ }^{1} \mathrm{H}^{-1} \mathrm{H}$ COSY spectrum of FD-891.

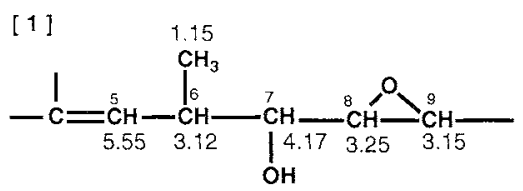

[2]

[3]

[ 4 ]
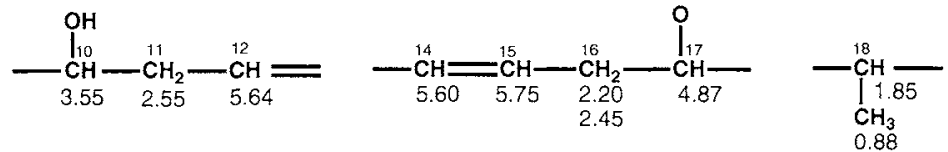

[5]

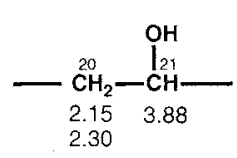

[6]

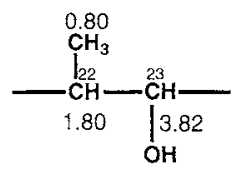

[ 7 ]

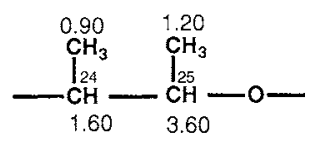

Fig. 3. Proton-carbon long range couplings detected by the HMBC method.

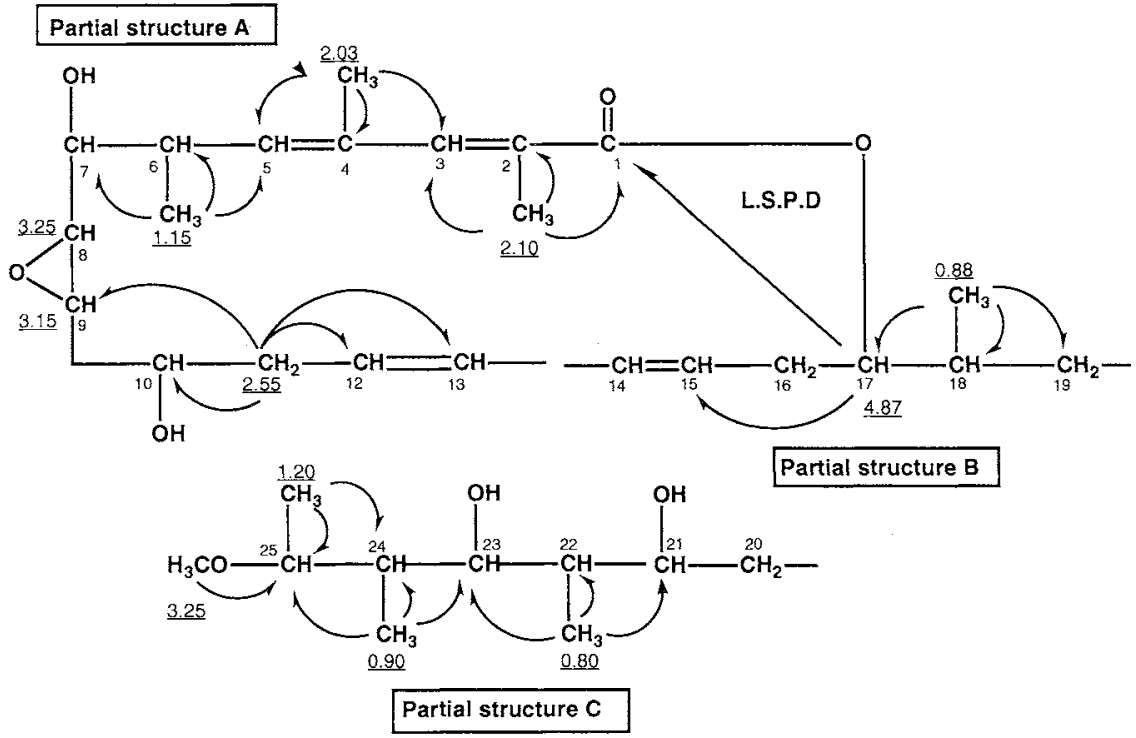

correlations with C-6 $\left(\delta_{\mathrm{C}} 35.9\right)$ and $\mathrm{C}-7\left(\delta_{\mathrm{C}} 70.7\right)$. Analysis of the HMBC spectrum allowed the partial structure from $\mathrm{C}-1$ to $\mathrm{C}-5$ to be assigned and connected with the fragment (1).

Long range cross peaks from almost equivalent methylen protons for $\mathrm{H}-11 \mathrm{~A}$ and $\mathrm{B}$ at $\delta_{\mathrm{H}} 2.55$, which showed a $\mathrm{A} 2$ type coupling pattern, to $\mathrm{C}-13\left(\delta_{\mathrm{C}} 129.3\right)$ and $\mathrm{C}-9\left(\delta_{\mathrm{C}} 56.0\right)$ made it possible to combine between the fragment (1) and the fragment (2), revealing the partial structure A as shown in Fig. 3.

The fragment (4) was expanded and connected with the fragment (3) by tracing ${ }^{1} \mathrm{H}^{13} \mathrm{C}$ long range couplings from the doublet methyl (18-Me) at $\delta_{\mathrm{H}} 0.88$ to the carbon signals for $\mathrm{C}-17\left(\delta_{\mathrm{C}} 76.7\right), \mathrm{C}-18\left(\delta_{\mathrm{C}}\right.$ $34.4)$ and $\mathrm{C}-19\left(\delta_{\mathrm{C}} 35.9\right)$, by which the partial structure B was deduced as depicted in Fig. 3. The signal 
at $\delta_{\mathrm{H}} 4.87$ corresponding to $\mathrm{H}-17$ did not shift downfield in the ${ }^{1} \mathrm{H}$ NMR of the acetyl derivative of FD-891, although the downfield shifts by $c a .1 .2 \sim 1.8$ ppm of the lines due to $\mathrm{H}-7, \mathrm{H}-10, \mathrm{H}-21$ and $\mathrm{H}-23$ were observed. An ester bond was determined to be formed by linking $\mathrm{C}-17$ to $\mathrm{C}-1$ as shown in Fig. 3, which could be confirmed by the observation of collapse of the signal for C-1 from a multiplet to a quartet at irradiation of $\mathrm{H}-17$ in the long range spin proton decoupling spectrum. These results led us to connect the partial structure A with the partial structure B. The ${ }^{1} \mathrm{H}$ NMR spectrum of a tetra acetyl dervative of FD-891 revealed that the four hydroxyl groups were located at C-7, C-10, C-21 and C-23, respectively.

The methyl signal $(22-\mathrm{Me})$ at $\delta_{\mathrm{H}} 0.80$ showed cross peaks with the carbons for $\mathrm{C}-21\left(\delta_{\mathrm{C}} 73.3\right), \mathrm{C}-22$ $\left(\delta_{\mathrm{C}} 39.5\right)$ and $\mathrm{C}-23\left(\delta_{\mathrm{C}} 78.2\right)$. A ${ }^{1} \mathrm{H}^{-13} \mathrm{C}$ long range coupling to $\mathrm{C}-23$ was observed from the doublet methyl $(\mathrm{C}-24)$ at $\delta_{\mathrm{H}} 0.90$, which in turn coupled to $\mathrm{C}-24\left(\delta_{\mathrm{C}} 35.9\right)$ and $\mathrm{C}-25\left(\delta_{\mathrm{C}} 82.5\right)$. Furthermore, the signals for $\mathrm{C}-24$ and $\mathrm{C}-25$ showed correlation peaks with the methyl $(25-\mathrm{Me})$ at $\delta_{\mathrm{H}} 1.20$. A cross peak from the OMe at $\delta_{\mathrm{H}} 3.25$ to the signal for C-25 led to the location of the OMe substituent at C-25. By the HMBC spectrum were thus unambiguously confirmed and combined the fragments (5), (6) and (7) with each other as shown in Fig. 3 (the partial structure C). The HMBC technique was a very useful method for combination with the partial structures of FD-891. However, further information on the connectivities could not be obtained by the HMBC technique.

To get more information and determine relayed connectivities, the Homonuclear Hartmann-Hahn (HOHAHA) ${ }^{8,9)}$ experiment was applied. The HOHAHA method faciliates determination of the relayed connectivities of protonated functionalities by propagation of magnetization one after another.

While refering to the ${ }^{1} \mathrm{H}-{ }^{1} \mathrm{H}$ COSY spectrum, respective cross peaks from $\mathrm{H}-21$ at $\delta_{\mathrm{H}} 3.88$ and $\mathrm{H}-17$ at $\delta_{\mathrm{H}} 4.87$ in the 2D HOHAHA spectrum allowed us to combine the methylene $\mathrm{H}-19 \mathrm{~A}$ and $-19 \mathrm{~B}$ at $\delta_{\mathrm{H}}$ 1.95 and 2.25 with the methylene $\mathrm{H}-20 \mathrm{~A}$ and $-20 \mathrm{~B}$ at $\delta_{\mathrm{H}} 2.15$ and 2.30. The 2D HOHAHA spectrum made up connection with the partial structures $B$ and $C$.

The remaining two olefinic functions at $\mathrm{H}-13$ and $\mathrm{H}-14$ were difficult to unequivocally distinguish and get a relation between them through the NMR methods because of their nearly identical chemical shifts. However, they were straightfowardly connected by taking into consideration the unsaturated degrees of FD-891 and the connectivities of the other functionalities. Thus, the structure of FD-891 was deduced as shown in Fig. 1.

Determination of the stereochemistry about the double bonds present in FD-891 was made by measurements of the NOEs and the ${ }^{3} J_{\mathbf{H}-\mathbf{H}}$ coupling constants. The NOEs were observed between $\mathrm{H}-3$ and $\mathrm{H}-5,4-\mathrm{Me}$ and 6-Me, indicating that the geometries of two double bonds from $\mathrm{C}-2$ to $\mathrm{C}-5$ were all trans. Because two pairs of coupled olefinic protons (H-12 and $\mathrm{H}-13, \mathrm{H}-14$ and $\mathrm{H}-15)$ had nearly identical chemical shifts, the coupling constants for these protons were measured from the $1 \mathrm{H}$-detected ${ }^{1} \mathrm{H}_{-}{ }^{13} \mathrm{C}$ shift correlation spectrum (HMQC) ${ }^{10}$, without ${ }^{13} \mathrm{C}$ decoupling ${ }^{1} \mathrm{H}$ data aquisition. This experiment showed coupling constant values between $\mathrm{H}-12$ and $\mathrm{H}-13, \mathrm{H}-14$ and $\mathrm{H}-15$ to be 15.5 and $15.2 \mathrm{~Hz}$, respectively, which revealed that the geometries of these two double bonds were all trans.

We have isolated not only FD-891 and FD-892 but also concanamycin A and its congeners FD-893, $894^{11,12)}$ from the fermentation broth of the same producing strain Streptomyces graminofaciens A- 8890 . Known biosynthetic studies on macrolide antibiotics such as erythromycin ${ }^{13)}$ suggested that these 18membered antibiotics may be produced through functions of the same multi-enzymes. From a biosynthetic view point, the stereochemistry of the macrolide ring of FD-891 might be the same as that of concanamycin A. The absolute stereochemistry of concanamycin $\mathrm{A}^{14)}$ was determined by an $\mathrm{X}$-ray analysis of its crystals 
Fig. 4. Stereochemistry of FD-891.
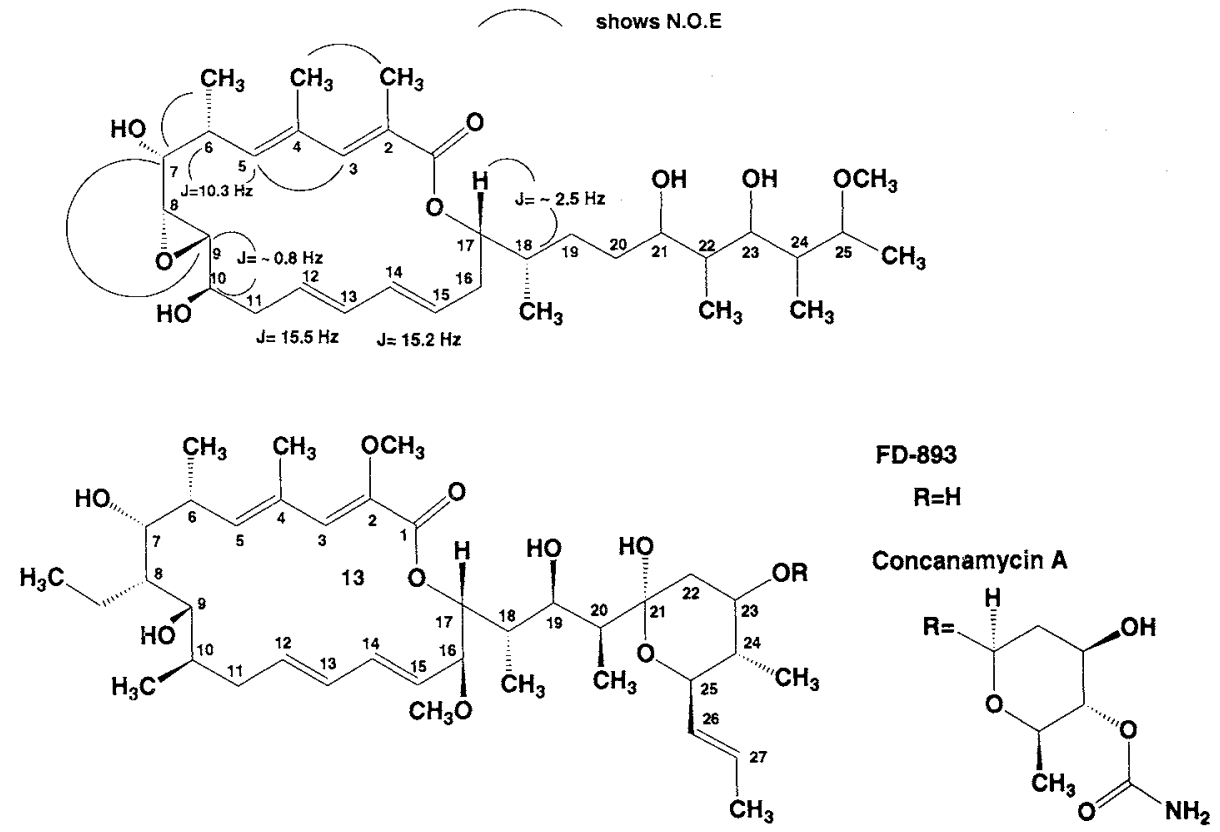

as shown in Fig. 4. Therefore, we examined stereochemistry on the macrolide ring of FD-891 by comparison with concanamycin A.

H-5 coupled to H-6 in FD-891 by $c a$. $10.3 \mathrm{~Hz}$ of identical coupling constant value with that of concanamycin A. Similarly in concanamycin A, NOEs between 6-Me and $\mathrm{H}-7, \mathrm{H}-6$ and $\mathrm{H}-7$ were observed in the NOESY spectrum of FD-891. Furthermore H-7 showed a cross peak with $\mathrm{H}-10$ in the NOESY spectrum of FD-891. ${ }^{3} J_{\mathrm{H}-\mathrm{H}}=\sim 2.5 \mathrm{~Hz}$ between $\mathrm{H}-8$ and $\mathrm{H}-9$ in the epoxy ring indicated that their stereochemical relationships was trans. The vicinal coupling constant value $(\sim 0.8 \mathrm{~Hz})$ between $\mathrm{H}-9$ and $\mathrm{H}-10$ suggested a torsion angle near $90^{\circ}$. As shown in Fig. 4. these results indicated that 6-Me, 7-OH and H-9 had $\alpha$ configurations whereas H-8 and 10-OH were $\beta$, in the same of FD-891as in concanamycin A. The coupling constant between $\mathrm{H}-17$ and $\mathrm{H}-18$ was very small $(\sim 2.5 \mathrm{~Hz})$ and it was difficult to trace a correlation peak of $\mathrm{H}-17$ and $\mathrm{H}-18$ in the ${ }^{1} \mathrm{H}-{ }^{1} \mathrm{H}$ COSY spectrum of FD-891 as well as that of concanamycin A. It was implicated that the stereochemistry at C-17 of FD-891 was identical with that of concanamycin A. To determine the stereochemistry of $1,3 \mathrm{diol}$ at $\mathrm{C}-21$ and $\mathrm{C}-23$ by application of analysis of ${ }^{13} \mathrm{C}$ NMR of acetonide derivatives ${ }^{15}$, we tried to synthesize an acetonide derivative of FD-891, however, we failed to obtain one because of decomposition of FD-891 by $p$-toluene sulfonic acid wich was used as catalyst. We will isolate a large quantity of FD-892 (vide infra) and synthesize its acetonide derivative in the near future to determine the stereochemistry at $\mathrm{C}-21$ and $\mathrm{C}-23$. The other stereochemistry remained to be assigned, and is now under study.

\section{Structure of FD-892}

The physico-chemical properties are shown in Table 1. The UV spectrum of FD-892 was very similar to that of FD-892, suggesting that its chromophore was the same as that of FD-891. Also, the IR spectrum of FD-892 showed the existence of a ester carbonyl at $1705 \mathrm{~cm}^{-1}$ and a hydroxy group at $3400 \mathrm{~cm}^{-1}$. 
FD-892 had a molecular formula of $\mathrm{C}_{32} \mathrm{H}_{52} \mathrm{O}_{6}$ established by the observation of its molecular ion at $m / z 532.3759$ (calcd. 532.3764 for $\mathrm{C}_{32} \mathrm{H}_{52} \mathrm{O}_{6}$ ) in the HREI-MS spectrum in combination with its NMR spectra. The molecular formula of FD-892 gave seven degree of unsaturation. The appearance of resonances for ten $s p^{2}$ carbons and a carbonyl group in the ${ }^{13} \mathrm{C}$ NMR spectrum indicated that 5 degrees of unsaturation were attributed to the presence of five double bonds and the last degree could be satisfied by assignment of one ring. By its ${ }^{1} \mathrm{H}$ and DEPT spectrum were only 49 hydrogens identified, revealing the presence of three hydroxyl groups in the molecule.

Since the physico-chemical properties of FD-892 were similar to those of FD-891, the structural assignment was initiated by comparison of the NMR spectra of FD-892 with those of FD-891.

The ${ }^{1} \mathrm{H}$ and ${ }^{13} \mathrm{C}$ NMR data are listed in Table 2 .

The ${ }^{13} \mathrm{C}$ NMR spectrum of FD-892 showed a similar spectral pattern to that of FD-891 except for the disappearance of the signals for $\mathrm{C}-8$ at $\delta_{\mathrm{C}} 55.1, \mathrm{C}-9$ at $\delta_{\mathrm{C}} 56.0, \mathrm{OCH}_{3}$ at $\delta_{\mathrm{C}} 56.0$ and $\mathrm{C}-10$ at $\delta_{\mathrm{C}} 71.0$, the appearance of the line at $\delta_{\mathrm{C}} 29.9$ and one pair of the protonated olefinic carbons at $\delta_{\mathrm{C}} 125.5$ and 133.2 and the downfield shift of the signal corresponding to $\mathrm{C}-25$ from $\delta_{\mathrm{C}} 72.8$ to $\delta_{\mathrm{C}} 82.2$. These spectral data indicated that the double bond was formed at C-8 and C-9 in place of an epoxide ring and that a hydroxyl group at $\mathrm{C}-10$ and a $\mathrm{OCH}_{3}$ group at $\mathrm{C}-25$ were lost in the molecule of $\mathrm{FD}-892$. In the ${ }^{1} \mathrm{H}$ NMR spectrum of FD-892 a $\mathrm{OCH}_{3}$ signal at $\delta_{\mathrm{H}} 3.34$ and two proton signals at $\delta_{\mathrm{H}} 3.15$ and 3.25 due to an epoxide ring disappeared and the increase of $2 \mathrm{H}$ of integeration value at the olefinic region from $\delta_{\mathrm{H}} 5.30$ to $\delta_{\mathrm{H}} 5.90$ was observed.

To unambiguously elucidate the structure, the NMR spectra was analyzed in detail. The HMBC experiment from the methyl signals at $\mathrm{C}-22, \mathrm{C}-24$ and $\mathrm{C}-25$ made it possible for the structure from $\mathrm{C}-21$ to $\mathrm{C}-25$ to be deduced, which indicated the replacement of the OMe by a hydroxyl group at $\mathrm{C}-25$. The upfieldshift by $9.8 \mathrm{ppm}$ at $\mathrm{C}-25$ was explained by well-known methylation shift.

By the HMBC method the same structure from C-1 to C-7 was elucidated as in FD-891. The signal due to $\mathrm{H}-7$ at $\delta_{\mathrm{H}} 3.85$ showed a cross peak of the line at $\delta_{\mathrm{H}} 5.34(\mathrm{H}-8)$, corresponding to the carbon at $\delta_{\mathrm{C}} 125.5$, which in turn coupled to the olefinic proton at $\delta_{\mathrm{H}} 5.78(\mathrm{H}-9)$. The signal at $\mathrm{H}-9$ matched with the line at $\delta_{\mathrm{C}} 133.2$ in the ${ }^{1} \mathrm{H}^{-13} \mathrm{C}$ COSY spectrum. Furthermore, the resonance of $\mathrm{H}-9$ coupled to an unequivalent methylene protons at $\delta_{\mathrm{H}} 1.95$ and 2.01 ( $\mathrm{H}-10 \mathrm{~A}$ and $\left.\mathrm{H}-10 \mathrm{~B}\right)$, which made up cross peaks of the line at $\delta_{\mathrm{C}} 29.9(\mathrm{C}-10)$ in the ${ }^{1} \mathrm{H}^{-13} \mathrm{C}$ spectrum. These spectral analysis led to the conclusion that an epoxide ring at C-8 and C-9 and a hydroxyl group at C-10 were lost and a duoble bond at C-8 and C-9 was formed in FD-892.

The measurement of $16.0 \mathrm{~Hz}$ of the coupling constant between $\mathrm{H}-8$ and $\mathrm{H}-9$ by the HMQC spectrum showed that the geometry of the double bond was $E$. The geometry of the other double bonds was the same as in FD-891. Both the ${ }^{1} \mathrm{H}$ and ${ }^{13} \mathrm{C}$ NMR spectra from C-10 to C-24 of FD-892 were basically the same as those of FD-891, indicating that both FD-891 and FD-892 had the same structure from C-10 to C-24. Thus, the structure of FD-892 was elucidated as shown in Fig. 1.

\section{Experimental}

General

IR spectra were recorded on a Perkin-Elmer 1760 FI-IR spectrophotometer. UV spectra were measured on a Hitachi 220A spectrophotometer. EI-MS and FAB-MS spectra were obtained with a JEOL JMX-SX 102 mass spectrometer. NMR spectra were measured on a JEOL JMN-GX 400 spectrometer at ambient 
temperature at $400 \mathrm{MHz}\left({ }^{1} \mathrm{H}\right)$ and $100 \mathrm{MHz}\left({ }^{13} \mathrm{C}\right)$ using the solvent peaks as internal references downfield of TMS at $0 \mathrm{ppm}$.

\section{A Tetra Acetyl Derivative of FD-891}

$15 \mathrm{mg}$ of FD- 891 was solved in $0.7 \mathrm{ml}$ of pyridine. To this solution was added $0.5 \mathrm{ml}$ of acetic anhydride and $3 \mathrm{mg}$ of 2 -methyl amino pyridine as a catalyst. The solution was stirred for 6 hours at room temperature. To the reaction mixture was added $20 \mathrm{ml}$ of cold water and then $20 \mathrm{ml}$ of ethyl acetate. The ethyl acetate layer was dried over $\mathrm{Na}_{2} \mathrm{SO}_{4}$ and concentrated in vacuo to give a solid material, which was subjected to LH-20 column chromatography developed with $\mathrm{MeOH}$. The fractions containing a tetra acetyl derivative was concentrated in vacuo to obtain $10 \mathrm{mg}$ of oily material. The mass and NMR spectral data of a tetra acetyl derivative of FD-891 thus obtained were as follows.

EI-MS $m / z 746\left(\mathrm{M}^{+}\right)$, FAB-MS $m / z 747(\mathrm{M}+\mathrm{H})^{+}, 769(\mathrm{M}+\mathrm{Na})^{+1} \mathrm{H}$ NMR (in $\left.\mathrm{CDCl}_{3}\right): \delta_{\mathrm{H}} 7.32(\mathrm{H}-4)$, 5.53 (H-5), 3.14 (H-6), 5.30 (H-7), 3.23 (H-8), 3.15 (H-9), 5.38 (H-10), $2.26(\mathrm{H}-11), 5.66(\mathrm{H}-12), 5.55$ (H-13), 5.60 (H-14), 5.77 (H-15), 2.20 (H-16A), 2.29 (H-16B), 4.87 (H-17), $1.84(\mathrm{H}-18), 1.95$ (H-19A), 2.25 (H-19B), $2.15(\mathrm{H}-20 \mathrm{~A}), 2.30(\mathrm{H}-20 \mathrm{~B}), 4.63(\mathrm{H}-21), 1.80(\mathrm{H}-22), 5.21(\mathrm{H}-23), 1.61(\mathrm{H}-24), 3.60(\mathrm{H}-25), 3.34$ $\left(-\mathrm{OCH}_{3}\right), 2.10\left(2-\mathrm{CH}_{3}\right), 2.03\left(4-\mathrm{CH}_{3}\right), 1.17\left(6-\mathrm{CH}_{3}\right), 0.89\left(18-\mathrm{CH}_{3}\right), 0.80\left(22-\mathrm{CH}_{3}\right), 0.90\left(24-\mathrm{CH}_{3}\right), 1.20$ $\left(25-\mathrm{CH}_{3}\right), 2.10\left(-\mathrm{OCOCH}_{3}\right), 2.11\left(-\mathrm{OCOCH}_{3}\right), 2.31\left(-\mathrm{OCOCH}_{3}\right), 2.33\left(-\mathrm{OCOCH}_{3}\right)$

\section{References}

1) Seki-Asano, M.; T. OKazaki, M. Yamagishi, N. Sakai, K. Hanada \& K. Mizoue: Isolation and characterization of new 18-membered macrolides FD-891 and FD-892. J. Antibiotics 47: 1226 1233, 1994

2) KINASHI, H.; K. IsONO \& K. SAKAGUCH: Isolation and characterization of concanamycins A, B and C. J. Antibiotics 37: $1333 \sim 1343,1984$

3) Kinashi, H \& K. SaKaguchl: Structure of concanamycin A. Tetrahedron Lett. 22: 3857 3860, 1981

4) Omura, S.; H. Shimizu, Y. Iwai, Kr. Hinotozawa, K. Otaguro, K. Hashimoto \& A. Nakagawa: AM-2604, a new antiviral antibiotic produced by a strain of Streptomyces. J. Antibiotics 35: 1632 1637, 1983

5) Omura, S.; N. Imamura, K. Hinotozawa, K. Otaguro, G. lukacs, R. Faghih, R. Tolman, B. H. Arison \& J. L. SMITH: The structure of virustomycin A. J. Antibiotics 36: $1783 \sim 1786,1983$

6) BAX, A. \& M. F. SUMmERs: ${ }^{1} \mathrm{H}$ and ${ }^{13} \mathrm{C}$ assignments from sensitivity enhanced detection of heteronuclear multi-bond connectivity by 2 D multiple quantum NMR. J. Am. Chem. Soc. 108: 2093 2094, 1986

7) Seto, H.; K. Furihata \& M. OhuchI: Particular utility of the HMBC technique to polypropionate derived metabolites as exemplified by erythromycin A. J. Antibiotics 41: 1158 1160, 1988

8) Davis, D. G. \& A. VAx: Assignment of complex ${ }^{1} \mathrm{H}$ NMR spectra via two-dimensional Homonuclear Hartmann-Hahn spectrometry J. Am. Chem Soc. 107: 2820 2821, 1985

9) Bax, A.; A. Aszalos, Z. Dinya \& K. Sudo: Structure elucidation of the antibiotic desertomycin through the use of new two-dimensional NMR techniques J. Am. Chem. Soc. 108: 8056 8063, 1986

10) BAX, A. \& S. Subramanian: Sensitivity-enhanced two-dimensional heteronuclear shift correlation NMR spectroscopy. J. Mag. Res. 67: 565 569, 1986

11) Mizoue, K; M. Asano, T. OKazaki, M. Yamagishi \& K. Hanada(taisho Pharmaceutical): New 18 membered macrolide compounds. Jpn. Pat. 2-229200 ('90), Aug. 30, 1990

12) Asano, M.; T. Okawaki, M. Yamaguchi, Y. Tsutida, K. Mizoue \& K. Hanada: New antitumor macrolides FD-891, 892. Abstract Papers Annual Meeting of the Agricultural Chemical Society of Japan, No. 3, p. 496, Kyoto, Mar. 30 Apr. 2, 1991

13) CANE, D. E.; Polyketide biosynthesis : molecular recognition or genetic programming. Science 263: $338 \sim 340,1994$

14) Westly, J. W.; C.-M. Liu, L. H. Evans, N. Troupe, J. F. Blount, A. M. Chiu, J. Todaro \& P. A. Miller: The structure and absolute configuration of the 18-membered macrolide lactone Antibiotic X-4357B (concanamycin A). J. Antibiotics 37: 1738 1740, 1984

15) Rychnovsky, S. D.; B. Rogers \& G. YANG: Analysis of two ${ }^{13} \mathrm{C}$ NMR correlations for determing stereochemistry of 1,3-diol acetonides. J. Org. Chem. 58: $3511 \sim 3515,1993$ 